\title{
Article \\ Cytotoxic 13,28 Epoxy Bridged Oleanane-Type Triterpenoid Saponins from the Roots of Ardisia crispa
}

\author{
Xin Yin ${ }^{+}\left(\mathbb{D}\right.$, Ruihang $\mathrm{Hu}^{\dagger}$, Yongqiang Zhou, Weiqian Zhu and Ying Zhou * \\ College of Pharmacy, Guizhou University of Traditional Chinese Medicine, Guiyang 550025, China; \\ yinxin110901@163.com (X.Y.); huruihang1997@163.com (R.H.); zhouxiaoqiang1988@126.com (Y.Z.); \\ zhuwq0820@163.com (W.Z.) \\ * Correspondence: Yingzhou71@sina.com; Tel.: +86-0851-88233090 \\ + These authors contributed equally to this work.
}

check for updates

Citation: Yin, X.; Hu, R.; Zhou, Y.; Zhu, W.; Zhou, Y. Cytotoxic 13,28 Epoxy Bridged Oleanane-Type Triterpenoid Saponins from the Roots of Ardisia crispa. Molecules 2022, 27, 1061. https://doi.org/10.3390/ molecules27031061

Academic Editor: Lillian Barros

Received: 20 January 2022

Accepted: 1 February 2022

Published: 4 February 2022

Publisher's Note: MDPI stays neutral with regard to jurisdictional claims in published maps and institutional affiliations.

Copyright: (C) 2022 by the authors. Licensee MDPI, Basel, Switzerland. This article is an open access article distributed under the terms and conditions of the Creative Commons Attribution (CC BY) license (https:// creativecommons.org/licenses/by/ $4.0 /)$.

\begin{abstract}
Ardisiacrispin D-F (1-3), three new 13,28 epoxy bridged oleanane-type triterpenoid saponins, together with four known analogues (4-7) were isolated from the roots of Ardisia crispa. The structures of 1-7 were elucidated based on 1D and 2D-NMR experiments and by comparing their spectroscopic data with values from the published literatures. Ardisiacrispin D-F (1-3) are first examples that the monosaccharide directly linked to aglycone C-3 of triterpenoid saponins in genus Ardisia are non-arabinopyranose. In the present paper, all compounds are evaluated for the cytotoxicity against three cancer cell lines (HeLa, HepG2 and U87 MG) in vitro. The results show that compounds 1, 4 and 6 exhibited significant cytotoxicity against Hela and U87 MG cells with IC 50 values in the range of $2.2 \pm 0.6$ to $9.5 \pm 1.8 \mu \mathrm{M}$. The present investigation suggests that roots of $A$. crispa could be a potential source of natural anti-tumor agents and their triterpenoid saponins might be responsible for cytotoxicity.
\end{abstract}

Keywords: Ardisia; oleanane-type triterpenoid; cytotoxicity; natural product

\section{Introduction}

The genus Ardisia (Primulaceae) is widely distributed in subtropical and tropical regions of the world, and, for along time, its roots have primarily been used as traditional medicines [1]. In previous phytochemical investigations, the chemical constituents of the genus Ardisia were reported to be saponins, isocoumarins, peptides, quinones and alkylphenols [1]. The roots of Ardisia species appeared to be a rich source of triterpenoid saponins, which have been isolated from various Ardisia species, including A. crenata, A. crispa, A. mamillata and $A$. pusilla. For example, novel triterpenoid saponins, ardisicrenosides A-B and ardisiacrispins A-B, were previously isolated from A. crenata and A. crispa, respectively [1]. Phytochemical investigations revealed that triterpenoid saponins are the main constituents of the genus Ardisia, and have significant cytotoxic activities [2-8]. Triterpenoid saponins reported from Ardisia plants are interesting from the viewpoints of chemical diversity and biological activity.

The roots of Ardisia crispa are utilized as traditional Chinese medicine for treating a sore throat, damp-heat jaundice and bruises [9]. Previous pharmacological studies on this plant have revealed that it has anti-tumor, anti-inflammatory and suppressed angiogenesis effects [10-18], but its chemical composition is rarely reported. In order to find more potentially cytotoxic triterpenoid saponins from A. crispa, an extract of the roots of this species was chemically investigated. Herein, the isolation, structural elucidation and the cytotoxic activities of the triterpenoid saponins are discussed.

\section{Results and Discussion}

Compound 1 was obtained as a white amorphous powder. Its molecular formula was deduced as $\mathrm{C}_{41} \mathrm{H}_{66} \mathrm{O}_{14}$ by HR-ESI-MS at $m / z 805.4317[\mathrm{M}+\mathrm{Na}]^{+}$(calcd. for $\mathrm{C}_{41} \mathrm{H}_{66} \mathrm{O}_{14} \mathrm{Na}$, 
805.4344). The ${ }^{1} \mathrm{H}-\mathrm{NMR}$ spectrum of $\mathbf{1}$ (Table 1 ) reveals the presence of 6 methyl proton signals of a typical oleanane-type triterpenoid skeleton [19] at $\delta_{\mathrm{H}} 0.99\left(3 \mathrm{H}, \mathrm{s}, \mathrm{H}_{3}-23\right), 0.78$ (3H, s, H $\left.\mathrm{H}_{3}-24\right), 0.91$ (3H, s, H $\left.\mathrm{H}_{3}-25\right), 1.08$ (3H, s, H3-26), 1.40 (3H, s, $\left.\mathrm{H}_{3}-27\right), 0.92$ (3H, s, $\left.\mathrm{H}_{3}-29\right)$; and 2 oxygen-bearing methylene protons $\delta_{\mathrm{H}} 3.55(1 \mathrm{H}, \mathrm{d}, J=11.1 \mathrm{~Hz}, \mathrm{H}-30 \mathrm{a})$, $3.25(1 \mathrm{H}, \mathrm{d}, J=11.1 \mathrm{~Hz}, \mathrm{H}-30 \mathrm{~b})$, together with 2 anomeric proton signals $\delta_{\mathrm{H}} 5.23(1 \mathrm{H}$, brs, $\left.\mathrm{H}-1^{\prime}\right)$ and $\delta_{\mathrm{H}} 4.44\left(1 \mathrm{H}, \mathrm{d}, J=7.8 \mathrm{~Hz}, \mathrm{H}-1^{\prime \prime}\right)$. The above ${ }^{1} \mathrm{H}-\mathrm{NMR}$ data, together with a carbonyl carbon signal at $\left(\delta_{\mathrm{C}} 181.0, \mathrm{C}-28\right)$ and an oxygenated quaternary carbon at $\left(\delta_{\mathrm{C}} 95.0\right.$, C-13) in the ${ }^{13} \mathrm{C}-\mathrm{NMR}$ spectrum, suggested 1 to be a 13,28 epoxy bridged oleanane-type triterpenoid skeleton in the aglycone and the presence of 2 sugar units [19]. The ${ }^{13} \mathrm{C}-\mathrm{NMR}$ data of the aglycon in $\mathbf{1}$ was similar to ardisicrenoside A, which was obtained previously from the Ardisia crenata, except for the presence of a carbon signal of $\gamma$-lactone moiety at C-28 $\left(\delta_{\mathrm{C}} 181.0\right)$ in 1 , rather than a oxygenated methylene carbon signal $\left(\delta_{\mathrm{C}} 77.5\right)$ in ardisicrenoside A [19]. The identity of the monosaccharides and the linkage of the sugar residues were made by the combination of DEPT-135, HSQC, ${ }^{1} \mathrm{H}-{ }^{1} \mathrm{H}$ COSY and HMBC spectra. The connectivity of the 2 sugars was mainly based on the HMBC correlations: $\mathrm{H}-\mathrm{1}^{\prime}$ $\left(\delta 5.23,1 \mathrm{H}\right.$, brs) with $\mathrm{C}-3\left(\delta_{\mathrm{C}} 89.4\right)$ of the aglycone, $\mathrm{H}-1 "{ }^{\prime \prime}\left(\delta_{\mathrm{H}} 4.44,1 \mathrm{H}, \mathrm{d}, J=7.8 \mathrm{~Hz}\right)$ with $\mathrm{C}-2^{\prime}\left(\delta_{\mathrm{C}} 89.6\right)$ (Figure 1$)$. By comparing the chemical shift signals and coupling constants of the sugar moieties from the published literature [20], the relative configurations of the anomeric centers of the arabinosyl and glucosyl moieties in $\mathbf{1}$ were determined to be $\alpha$ and $\beta$, respectively. The two kinds of sugars, L-arabinofuranose and D-glucose, were identified by GC analysis after derivatization.

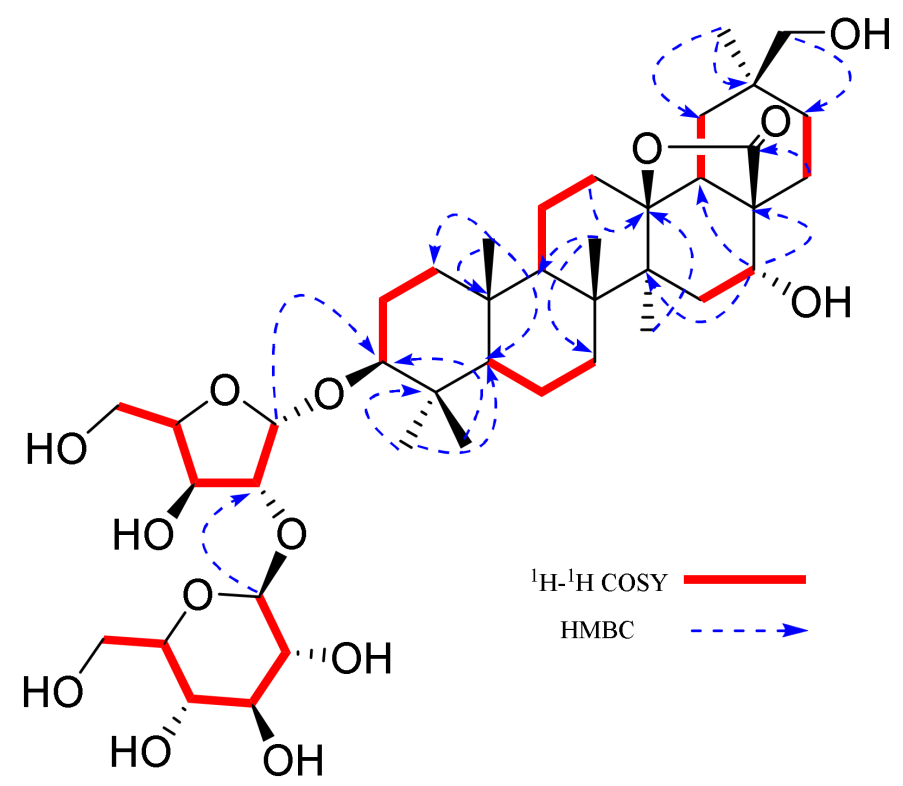

Figure 1. Key $\mathrm{HMBC}$ and ${ }^{1} \mathrm{H}-{ }^{1} \mathrm{H}$ COSY correlations of ardisiacrispin D (1).

The NOESY correlations (Figure 2) of Me-23 $\alpha / \mathrm{H}-3 \alpha, \mathrm{H}-5 \alpha ; \mathrm{H}-5 \alpha / \mathrm{H}-9 \alpha ; \mathrm{H}-9 \alpha / \mathrm{Me}-27 \alpha$; $\mathrm{Me}-24 \beta / \mathrm{Me}-25 \beta$, Me-25 $\beta / \mathrm{Me}-26 \beta ; \mathrm{H}-18 \beta / \mathrm{H}-16 \beta, \mathrm{H}-30 \beta$ indicated the $\alpha$-orientation of H-3 and $\beta$-orientation of H-16. Thus, 1 was inferred as $3 \beta, 16 \alpha, 30$-trihydroxyolean-13 $\beta$,28olide-3-O- $\beta$-D-glucopyranosyl- $(1 \rightarrow 2)-\alpha$-L-arabinofuranose, and named as ardisiacrispin D (Figure 3). 


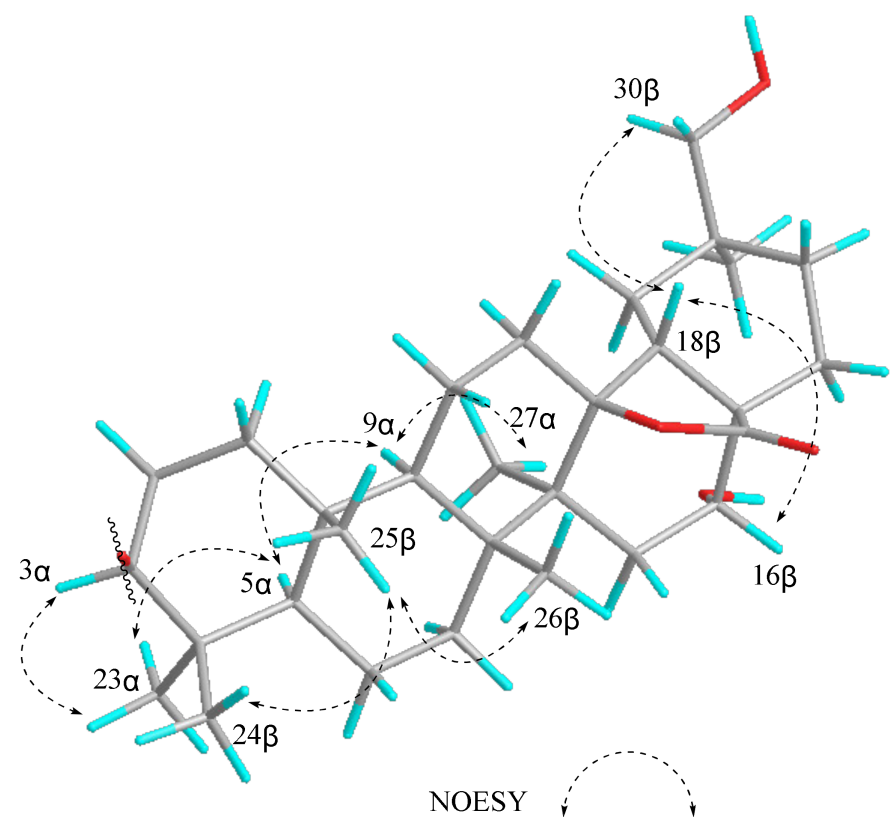

Figure 2. Key NOESY correlations of the aglycon of ardisiacrispin D (1).
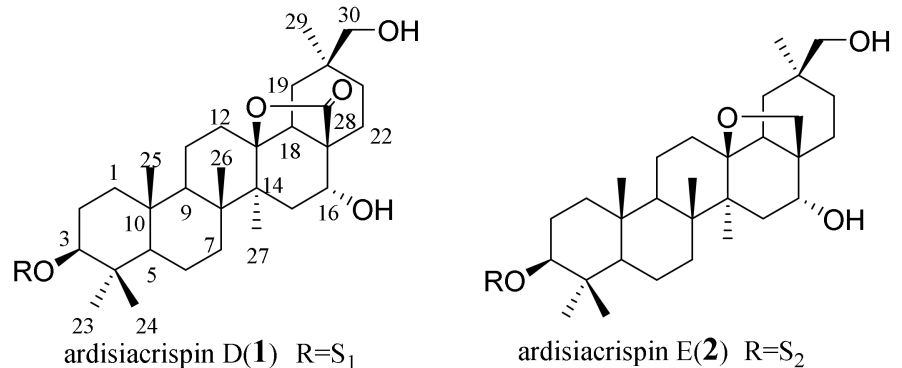

ardisiacrispin $\mathrm{E}(\mathbf{2}) \mathrm{R}=\mathrm{S}_{2}$

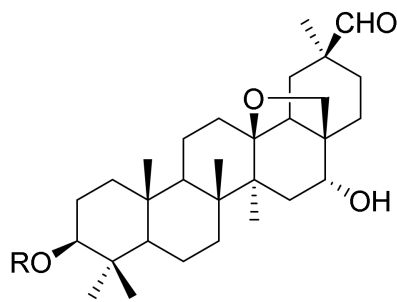

$\operatorname{ardisiacrispin} \mathrm{F}(\mathbf{3}) \quad \mathrm{R}=\mathrm{S}_{3}$

$4 \mathrm{R}=\mathrm{S}_{4}$

$\begin{array}{ll}5 & \mathrm{R}=\mathrm{S}_{5} \\ 6 & \mathrm{R}=\mathrm{S}_{6}\end{array}$

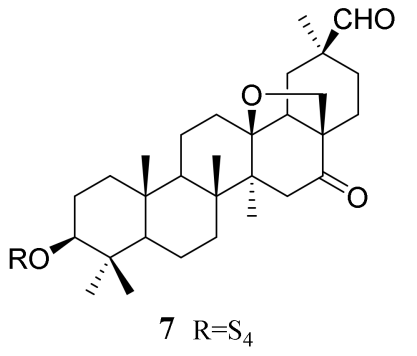

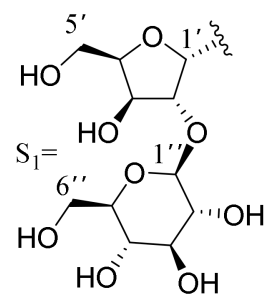

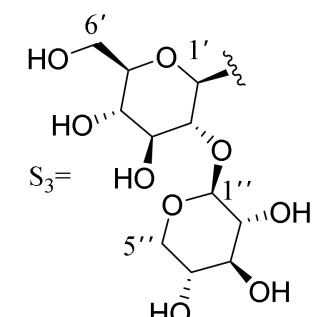

$\mathrm{HO}$<smiles>C[C@@H]1OCC(OC2OC(CO)[C@@H](O)[C@H](O)C2O)C(O)C1O</smiles><smiles>CC1OCC(O)C(O)C1O</smiles>

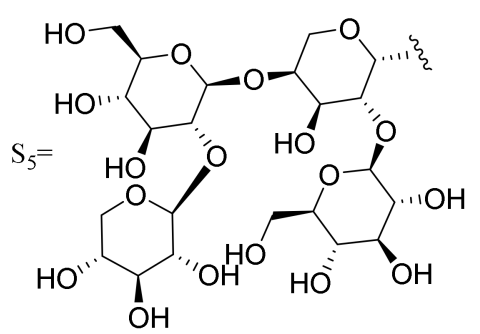

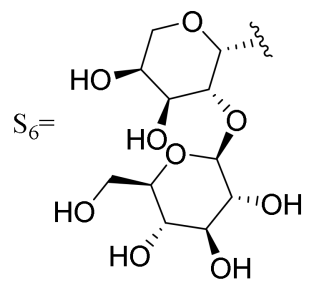

Figure 3. Chemical structures of compounds 1-7. 
Compound 2 was separated as a white amorphous powder. The molecular formula of 2 was established to be $\mathrm{C}_{42} \mathrm{H}_{70} \mathrm{O}_{14}$ from its HR-ESI-MS at $m / z 821.4628[\mathrm{M}+\mathrm{Na}]^{+}$(calcd. for 821.4657). In the ${ }^{1} \mathrm{H}$ and ${ }^{13} \mathrm{C}-\mathrm{NMR}$ spectrum of 2 (Table 1 ), signals due to an aglycone moiety were similar with those of ardisicrenoside B [19], although the signals due to the sugar moiety were not identical. The NMR data of $\mathbf{2}$ showed two anomeric proton signals at $\delta_{\mathrm{H}} 4.39\left(1 \mathrm{H}, \mathrm{d}, J=7.8 \mathrm{~Hz}, \mathrm{H}-1^{\prime}\right)$ and $4.65\left(1 \mathrm{H}, \mathrm{d}, J=7.7 \mathrm{~Hz}, \mathrm{H}-1^{\prime \prime}\right)$, corresponding to two anomeric carbons at $\delta_{\mathrm{C}} 105.9$ and 104.6 in the HSQC spectrum, indicating the presence of two sugar moieties. The attachments of the sugar chain were deduced from the HMBC spectrum. The HMBC showed that there was a correlation between $\mathrm{H}-1^{\prime}\left(\delta_{\mathrm{H}} 4.39,1 \mathrm{H}, \mathrm{d}\right.$, $J=7.8 \mathrm{~Hz})$ and C-3 $\left(\delta_{\mathrm{C}} 91.3\right)$ of the aglycone; $\mathrm{H}-1^{\prime \prime}\left(\delta_{\mathrm{H}} 4.65,1 \mathrm{H}, \mathrm{d}, J=7.7 \mathrm{~Hz}\right)$ and C-2' $\left(\delta_{\mathrm{C}} 79.1\right)$ indicated that the sugar chain was connected to $\mathrm{C}-3$ of the aglycone, and the terminal sugar was linked to C-2'. The anomeric configuration of these 2 glucoses were determined to be $\beta$ on the basis of the $J$ value of the anomeric proton in glucose $(J=7.8$ and $7.7 \mathrm{~Hz}$ )]. The relative configurations of 2 were determined by the NOESY experiment, which were consistent with those of $\mathbf{1}$. On the basis of above evidence, the structure of 2 was identified to be $3 \beta, 16 \alpha, 30$-trihydroxyolean-13 $\beta, 28$-epoxy-3-O- $\beta$-D-glucopyranosyl$(1 \rightarrow 2)-\beta$-D-glucopyranose, and named as ardisiacrispin E.

Table 1. ${ }^{1} \mathrm{H}$ and ${ }^{13} \mathrm{C}-\mathrm{NMR}$ data of compounds $1-3$ in methanol- $d_{4}(\delta$ in ppm).

\begin{tabular}{|c|c|c|c|c|c|c|}
\hline \multirow[b]{2}{*}{ Position } & \multicolumn{2}{|r|}{1} & \multicolumn{2}{|r|}{2} & \multicolumn{2}{|r|}{3} \\
\hline & $\delta_{\mathrm{C}}$ & $\delta_{\mathrm{H}}(J$ in $\mathrm{Hz})$ & $\delta_{\mathrm{C}}$ & $\delta_{\mathrm{H}}(J$ in $\mathrm{Hz})$ & $\delta_{\mathrm{C}}$ & $\delta_{\mathrm{H}}(J$ in $\mathrm{Hz})$ \\
\hline \multirow{2}{*}{1} & \multirow{2}{*}{40.0} & $1.78(\mathrm{~m})$ & \multirow{2}{*}{40.2} & $1.73(\mathrm{~m})$ & \multirow{2}{*}{40.2} & $1.73(\mathrm{~m})$ \\
\hline & & $0.98(\mathrm{~m})$ & & $1.00(\mathrm{~m})$ & & $0.97(\mathrm{~m})$ \\
\hline \multirow{2}{*}{2} & \multirow{2}{*}{26.7} & $1.96(\mathrm{~m})$ & \multirow{2}{*}{27.3} & $1.95(\mathrm{~m})$ & \multirow{2}{*}{27.3} & $1.85(\mathrm{~m})$ \\
\hline & & $1.67(\mathrm{~m})$ & & $1.70(\mathrm{~m})$ & & $1.70(\mathrm{~m})$ \\
\hline 3 & 89.4 & 3.15 (overlap) & 91.3 & 3.16 (overlap) & 91.3 & $3.14(\mathrm{dd}, 11.3,4.2)$ \\
\hline 4 & 40.0 & - & 40.5 & - & 40.6 & - \\
\hline 5 & 56.5 & $0.79(\mathrm{brd}, 7.1)$ & 56.8 & 0.72 (brd, 11.1) & 56.8 & 0.72 (brd, 9.7) \\
\hline \multirow{2}{*}{6} & \multirow{2}{*}{18.8} & $1.51(\mathrm{~m})$ & \multirow{2}{*}{18.7} & $1.51(\mathrm{~m})$ & \multirow{2}{*}{18.7} & $1.49(\mathrm{~m})$ \\
\hline & & $1.46(\mathrm{~m})$ & & $1.42(\mathrm{~m})$ & & $1.42(\mathrm{~m})$ \\
\hline \multirow{2}{*}{7} & \multirow{2}{*}{34.8} & $1.59(\mathrm{~m})$ & \multirow{2}{*}{35.1} & $1.56(\mathrm{~m})$ & \multirow{2}{*}{35.1} & $1.54(\mathrm{~m})$ \\
\hline & & $1.24(\mathrm{~m})$ & & $1.20(\mathrm{~m})$ & & $1.20(\mathrm{~m})$ \\
\hline 8 & 43.1 & - & 43.3 & - & 43.4 & - \\
\hline 9 & 50.8 & 1.35 (overlap) & 51.6 & 1.46 (overlap) & 51.3 & 1.24 (overlap) \\
\hline 10 & 37.8 & - & 37.7 & - & 37.8 & - \\
\hline \multirow{2}{*}{11} & \multirow{2}{*}{19.4} & $1.65(\mathrm{~m})$ & \multirow{2}{*}{19.8} & $1.64(\mathrm{~m})$ & \multirow{2}{*}{19.8} & $1.63(\mathrm{~m})$ \\
\hline & & $1.50(\mathrm{~m})$ & & $1.48(\mathrm{~m})$ & & $1.48(\mathrm{~m})$ \\
\hline \multirow{2}{*}{12} & \multirow{2}{*}{32.1} & $2.16(\mathrm{~m})$ & \multirow{2}{*}{32.8} & $2.05(\mathrm{~m})$ & \multirow{2}{*}{33.2} & $2.10(\mathrm{~m})$ \\
\hline & & $1.56(\mathrm{~m})$ & & $1.33(\mathrm{~m})$ & & $1.26(\mathrm{~m})$ \\
\hline 13 & 95.0 & - & 88.5 & - & 88.2 & - \\
\hline 14 & 43.0 & - & 45.3 & - & 45.3 & - \\
\hline \multirow{2}{*}{15} & 374 & 1.78 (overlap) & 369 & 2.08 (overlap) & & $2.07(\mathrm{~m})$ \\
\hline & 37.4 & 1.44 (overlap) & 36.9 & 1.20 (overlap) & 37.0 & $1.20(\mathrm{~m})$ \\
\hline 16 & 73.3 & 3.96 (brd, 5.2) & 78.0 & 3.89 (overlap) & 77.8 & 3.91 (brd, 4.9) \\
\hline 17 & 49.5 & - & 45.2 & - & 44.8 & - \\
\hline 18 & 51.9 & $1.85(\mathrm{~m})$ & 51.3 & $1.24(\mathrm{~m})$ & 54.0 & $1.12(\mathrm{dd}, 12.9,2.1)$ \\
\hline 19 & 331 & $2.35(\mathrm{t}$, like, 12.4$)$ & 338 & $2.25(\mathrm{t}$, like, 12.6$)$ & 340 & $2.50(\mathrm{dd}, 14.2,12.9)$ \\
\hline 19 & 33.1 & $1.68(\mathrm{~m})$ & 33.8 & $1.58(\mathrm{~m})$ & 34.0 & $1.96(\mathrm{dd}, 14.2,2.1)$ \\
\hline 20 & 36.7 & - & 36.9 & - & 49.2 & - \\
\hline 21 & 323 & $2.03(\mathrm{~m})$ & 332 & $2.04(\mathrm{~m})$ & 308 & $2.12(\mathrm{~m})$ \\
\hline 21 & 32.3 & $1.35(\mathrm{~m})$ & 33.2 & $1.28(\mathrm{~m})$ & 30.8 & $1.89(\mathrm{~m})$ \\
\hline 22 & 286 & $1.84(\mathrm{~m})$ & 210 & $1.72(\mathrm{~m})$ & 220 & $1.84(\mathrm{~m})$ \\
\hline & 28.6 & $1.60(\mathrm{~m})$ & 31.8 & $1.45(\mathrm{~m})$ & 32.8 & $1.32(\mathrm{~m})$ \\
\hline
\end{tabular}


Table 1. Cont.

\begin{tabular}{|c|c|c|c|c|c|c|}
\hline \multirow[b]{2}{*}{ Position } & \multicolumn{2}{|r|}{1} & \multicolumn{2}{|r|}{2} & \multicolumn{2}{|r|}{3} \\
\hline & $\delta_{\mathrm{C}}$ & $\delta_{\mathrm{H}}(J$ in $\mathrm{Hz})$ & $\delta_{\mathrm{C}}$ & $\delta_{\mathrm{H}}(J$ in $\mathrm{Hz})$ & $\delta_{\mathrm{C}}$ & $\delta_{\mathrm{H}}(J$ in $\mathrm{Hz})$ \\
\hline 23 & 28.7 & $0.99(\mathrm{~s})$ & 28.3 & $1.06(\mathrm{~s})$ & 28.3 & $1.05(\mathrm{~s})$ \\
\hline 24 & 16.8 & $0.78(\mathrm{~s})$ & 16.7 & $0.83(\mathrm{~s})$ & 16.7 & $0.83(\mathrm{~s})$ \\
\hline 25 & 16.7 & $0.91(\mathrm{~s})$ & 16.7 & $0.89(\mathrm{~s})$ & 16.7 & $0.89(\mathrm{~s})$ \\
\hline 26 & 18.2 & $1.08(\mathrm{~s})$ & 18.8 & $1.14(\mathrm{~s})$ & 18.8 & $1.13(\mathrm{~s})$ \\
\hline 27 & 19.8 & $1.40(\mathrm{~s})$ & 20.0 & $1.25(\mathrm{~s})$ & 20.1 & $1.27(\mathrm{~s})$ \\
\hline 28 & 181.0 & (1) & 78.6 & $\begin{array}{l}3.50(\mathrm{~d}, 7.6) \\
3.10(\mathrm{~d}, 7.6)\end{array}$ & 78.4 & $\begin{array}{l}3.48(\mathrm{~d}, 7.6) \\
2.98(\mathrm{~d}, 7.6)\end{array}$ \\
\hline 29 & 28.3 & $0.92(\mathrm{~s})$ & 28.5 & $0.92(\mathrm{~s})$ & 24.3 & $0.97(\mathrm{~s})$ \\
\hline 30 & 66.5 & $\begin{array}{l}3.55(\mathrm{~d}, 11.1) \\
3.25(\mathrm{~d}, 11.1)\end{array}$ & 66.5 & $\begin{array}{l}3.55(\mathrm{~d}, 10.9) \\
3.30(\mathrm{~d}, 10.9)\end{array}$ & 209.2 & $9.40(\mathrm{~s})$ \\
\hline $1^{\prime}$ & 110.2 & 5.23 (brs) & 105.9 & $4.39(\mathrm{~d}, 7.8)$ & 106.0 & $4.40(\mathrm{~d}, 7.0)$ \\
\hline $2^{\prime}$ & 89.6 & $4.21(\mathrm{~d}, 5.2)$ & 79.1 & $3.87(\mathrm{~m})$ & 80.9 & $3.56(\mathrm{~m})$ \\
\hline $3^{\prime}$ & 75.8 & $4.26(\mathrm{dd}, 5.2,2.0)$ & 76.3 & $3.20(\mathrm{~m})$ & 78.0 & $3.53(\mathrm{~m})$ \\
\hline $4^{\prime}$ & 83.9 & $4.19(\mathrm{~m})$ & 70.3 & $3.83(\mathrm{~m})$ & 71.1 & $3.49(\mathrm{~m})$ \\
\hline $5^{\prime}$ & 62.5 & $\begin{array}{l}3.83(\mathrm{dd}, 11.6,4.9) \\
3.75(\mathrm{dd}, 11.6,6.4)\end{array}$ & 76.2 & $3.47(\mathrm{~m})$ & 78.4 & $3.47(\mathrm{~m})$ \\
\hline $6^{\prime}$ & - & 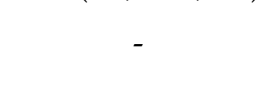 & 62.3 & $\begin{array}{l}3.72 \text { (overlap) } \\
3.70 \text { (overlap) }\end{array}$ & 63.0 & $\begin{array}{l}3.81(\mathrm{dd}, 11.9,2.0) \\
3.60(\mathrm{dd}, 11.9,5.8)\end{array}$ \\
\hline $1^{\prime \prime}$ & 104.2 & $4.44(\mathrm{~d}, 7.8)$ & 104.6 & $4.65(\mathrm{~d}, 7.7)$ & 104.6 & $4.65(\mathrm{~d}, 7.7)$ \\
\hline $2^{\prime \prime}$ & 75.0 & $3.18(\mathrm{~m})$ & 75.4 & $3.66(\mathrm{~m})$ & 76.2 & $3.20(\mathrm{~m})$ \\
\hline $3^{\prime \prime}$ & 78.0 & $3.25(\mathrm{~m})$ & 78.2 & $3.22(\mathrm{~m})$ & 77.9 & $3.33(\mathrm{~m})$ \\
\hline $4^{\prime \prime}$ & 71.3 & $3.36(\mathrm{~m})$ & 71.9 & $3.21(\mathrm{~m})$ & 71.9 & $3.21(\mathrm{~m})$ \\
\hline $5^{\prime \prime}$ & 77.9 & $3.34(\mathrm{~m})$ & 77.9 & $3.34(\mathrm{~m})$ & 66.5 & $\begin{array}{l}3.84 \text { (overlap) } \\
3.17 \text { (overlap) }\end{array}$ \\
\hline $6^{\prime \prime}$ & 62.4 & $\begin{array}{l}3.85(\mathrm{dd}, 12.0,2.5) \\
3.72(\mathrm{dd}, 12.0,5.0)\end{array}$ & 63.1 & $\begin{array}{l}3.81(\mathrm{dd}, 11.9,2.2) \\
3.61(\mathrm{dd}, 11.9,5.9)\end{array}$ & - & 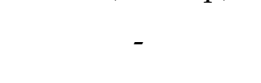 \\
\hline
\end{tabular}

Compound 3 was isolated as white amorphous powder. The molecular formula was inferred as $\mathrm{C}_{41} \mathrm{H}_{66} \mathrm{O}_{13}$ according to the positive-ion HR-ESI-MS peak at $m / z 789.4367[\mathrm{M}+\mathrm{Na}]^{+}$ (calcd for $\mathrm{C}_{41} \mathrm{H}_{66} \mathrm{O}_{13} \mathrm{Na}$, 789.4395). The NMR spectra of the aglycone of 3 closely resembled that of 2 (Table 1$)$, except for ${ }^{13} \mathrm{C}-\mathrm{NMR}$ signals of C-20 $\left(\delta_{\mathrm{C}} 36.9\right), \mathrm{C}-29\left(\delta_{\mathrm{C}} 28.5\right)$ and C-30 $\left(\delta_{\mathrm{C}}\right.$ 66.5) in 2, which were shifted to $\delta_{\mathrm{C}} 49.2,24.3$ and 209.2 in 3, respectively. Moreover, the singlet observed at $\delta_{\mathrm{H}} 9.40$ was assigned as a formyl proton. The above NMR data suggested that C-30 in 3 was substituted with a formyl group, which was supported by the HMBC correlations from H-29/H-30 to C-20 and from H-29 to C-19, C-21 and C-30. The NMR data for the sugar moiety and GC analysis of the derivatives of the hydrolyzate of 3 indicated the existence of D-xylopyranose and D-glucopyranose. The anomeric proton signals of $\mathbf{3}$ at $\delta_{\mathrm{H}} 4.40\left(1 \mathrm{H}, \mathrm{d}, J=7.0 \mathrm{~Hz}, \mathrm{H}-1^{\prime}\right)$ and $4.65\left(1 \mathrm{H}, \mathrm{d}, J=7.7 \mathrm{~Hz}, \mathrm{H}-1^{\prime \prime}\right)$, led to the assignment of the anomeric configurations of glucose and xylose units as $\beta$ due to their relatively large coupling constants $(J$ values $>7)$. In the HMBC spectrum, the long-range correlations of $\delta_{\mathrm{H}} 4.40\left(1 \mathrm{H}, \mathrm{d}, J=7.0 \mathrm{~Hz}, \mathrm{H}-1^{\prime}\right)$ with $\delta_{\mathrm{C}} 91.3(\mathrm{C}-3)$ and $\delta_{\mathrm{H}} 4.65\left(1 \mathrm{H}, \mathrm{d}, J=7.7 \mathrm{~Hz}, \mathrm{H}-1^{\prime \prime}\right)$ with $\delta_{\mathrm{C}} 80.9\left(\mathrm{C}-2^{\prime}\right)$ were observed. The ${ }^{1} \mathrm{H}$ and ${ }^{13} \mathrm{C}-\mathrm{NMR}$ spectra of the sugar parts of 3 were in accordance with those of majonoside-R2 [21]. The relative configurations of $\mathbf{3}$ were determined by the NOESY experiment, which were consistent with those of $\mathbf{2}$. Therefore, the structure of 3 was identified as $3 \beta, 16 \alpha$ dihydroxyolean-13 $\beta, 28$-epoxy-30-al-3-O- $\beta$-Dxylopyranosyl-(1 $\rightarrow 2)-\beta$-D-glucopyranose, and named as ardisiacrispin $\mathrm{F}$.

By NMR data analysis and comparison with the reported spectroscopic data, four known compounds were identified as 3-O- $\alpha$-L-rhamnopyranosyl-( $1 \rightarrow 2)-\beta$-D-glucopyranosyl$(1 \rightarrow 4)$ - $\alpha$-L-arabinopyranosyl-cyclamiretin A (4) [22]; ardisiacrispin A (5) [19]; 3-O- $\beta$-Dglucopyranosyl-(1 $\rightarrow 2)-\alpha$-L-arabinopyranoside-cyclamiretin A (6) [23]; and ardisimamillosides H (7) [24] (Supporting Information).

To date, the monosaccharide directly linked to aglycone C-3 of triterpenoid saponins reported in Ardisia are all arabinopyranose. In this study, we reported three novel triter- 
penoid saponins from Ardisia crispa with arabinofuranosyl and glucosyl groups directly connected to aglycone C-3 for the first time. Therefore, the above results are of great significance to elucidate the biosynthesis of triterpenoid saponins in genus Ardisia.

In addition, all the isolates (1-7) were tested for their cytotoxicity against the HeLa, HepG2 and U87 MG cell lines using the MTT method. The results (Table 2) show that the compounds $(\mathbf{1}, \mathbf{4}$ and $\mathbf{6})$ exhibited more significant cytotoxic activities than cisplatin (Sigma, $>99 \%$ ), which was used as a positive control. Due to the limited numbers of active compounds, only the superficial and primary structure-activity relationships were discussed. Compared with compounds 4-7, 1-3 showed stronger cytotoxicity against Hela cells, which suggested that the non-arabinopyranose directly linked to aglycone C-3 might make a contribution to their cytotoxicity. However, The $\mathrm{IC}_{50}$ values of compounds 2 and 3 on HepG2 cells were higher than 4-6, which might be caused by the arabinopyranosyl group in 4-6. Compound 5 exhibited better cytotoxic activity against U87 MG cells compared with 1-4 and 6-7, which demonstrated that the number of monosaccharide may affect the activity.

Table 2. Cytotoxic activities of compounds 1-7 against three human tumor cell lines (HeLa, HepG2 and $\mathrm{U} 87 \mathrm{MG}$ ) (mean $\pm \mathrm{SD}, n=3)$.

\begin{tabular}{cccc}
\hline \multirow{2}{*}{ Compounds } & \multicolumn{3}{c}{ IC $_{\mathbf{5 0}}$ (Mean \pm SD $\boldsymbol{\mu M}$ ) } \\
\cline { 2 - 4 } & HeLa & HepG2 & U87 MG \\
\hline 1 & $3.2 \pm 0.7$ & $8.8 \pm 2.2$ & $5.7 \pm 1.8$ \\
2 & $4.4 \pm 1.1$ & $21.9 \pm 6.1$ & $6.8 \pm 2.2$ \\
3 & $2.2 \pm 0.6$ & $33.6 \pm 6.8$ & $7.7 \pm 0.9$ \\
4 & $6.8 \pm 1.2$ & $7.9 \pm 2.2$ & $6.6 \pm 1.6$ \\
5 & $9.5 \pm 1.8$ & $14.4 \pm 2.1$ & $2.3 \pm 0.4$ \\
6 & $5.4 \pm 0.9$ & $8.7 \pm 1.2$ & $6.8 \pm 1.1$ \\
7 & $5.2 \pm 1.3$ & $38.2 \pm 6.6$ & $5.4 \pm 0.9$ \\
Cisplatin $^{a}$ & $9.8 \pm 0.4$ & $12.1 \pm 0.3$ & $16.7 \pm 0.8$ \\
\hline
\end{tabular}

${ }^{a}$ Positive control.

\section{Materials and Methods}

\subsection{General Experimental Procedures}

Optical rotations were measured on a JASCO P-2000 instrument. The 1D and 2D NMR spectra were recorded on either a Bruker DPX 400 instrument with tetramethylsilane as an internal standard and $\mathrm{MeOH}-d_{4}$ as a solvent. HR-ESI-MS experiments were conducted using a Thermo Fisher QE Focus spectrometer. The semi-preparative HPLC procedure was conducted on a Shimadzu LC-16D instrument with an RID-20A (reflective index detector) and a reversed-phase $\mathrm{C}_{18}$ column $(250 \times 10 \mathrm{~mm}, 5 \mu \mathrm{m}$, Waters SunFire). Column chromatography was performed using silica gel (200-300 mesh, China), octadecyl silica (ODS) (50 $\mu \mathrm{m}$, Merck, Germany).

\subsection{Plant Material}

The roots of Ardisia crispa were collected from Kaili of Guizhou Province (China), and identified by Professor Sheng-Hua Wei from Guizhou University of Traditional Chinese Medicine. The voucher specimen (No. 20190502) was deposited at Guizhou University of Traditional Chinese Medicine.

\subsection{Extraction and Isolation}

The air-dried A. crispa roots $(7.0 \mathrm{~kg})$ were extracted under reflux with $70 \% \mathrm{EtOH}$. The filtrates were concentrated on a rotary evaporator (EYELA, N-1300 type) under reduced pressure to yield $1900 \mathrm{~g}$ of crude extract. The crude extract was partitioned with petroleum ether, EtOAc and $n-\mathrm{BuOH}$ successively, yielding $n-\mathrm{BuOH}(360.0 \mathrm{~g})$ extracts. The $n-\mathrm{BuOH}-$ rich fraction (290 g) was subjected to silica gel column chromatography eluting with gradient mixtures of $\mathrm{CH}_{2} \mathrm{Cl}_{2}-\mathrm{CH}_{3} \mathrm{OH}$ (1:0-0:1) to produce compound 5 (56.3 g) and 9 main 
fractions (Fr. A-Fr. I). Fraction G (12.0 g) was chromatographed on an ODS column with $\mathrm{MeOH}-\mathrm{H}_{2} \mathrm{O}$ (1:9 to 1:0) to afford sub-fractions G1-G7. Sub-fraction G5 (870 mg) was separated by semi-preparative HPLC $\left(\mathrm{MeOH}-\mathrm{H}_{2} \mathrm{O}, 71: 29\right.$; flow rate: $\left.3 \mathrm{~mL} \cdot \mathrm{min}^{-1}\right)$ to create compound 7 (9.2 $\left.\mathrm{mg}, t_{R} 16.5 \mathrm{~min}\right)$, compound $1\left(3.4 \mathrm{mg}, t_{R} 18.8 \mathrm{~min}\right)$ and compound 3 $\left(4.2 \mathrm{mg}, t_{R} 21.5 \mathrm{~min}\right)$. Sub-fraction G6 $(620 \mathrm{mg})$ was purified by semi-preparative HPLC $\left(\mathrm{MeOH}-\mathrm{H}_{2} \mathrm{O}, 78: 22\right.$; flow rate: $\left.3 \mathrm{~mL} \cdot \mathrm{min}^{-1}\right)$ to yield compound $4\left(11.0 \mathrm{mg}, t_{R} 15.4 \mathrm{~min}\right)$, compound 2 (3.8 $\left.\mathrm{mg}, t_{R} 18.7 \mathrm{~min}\right)$ and compound $6\left(13.0 \mathrm{mg}, t_{R} 21.6 \mathrm{~min}\right)$.

\subsection{Characterization of Compounds $\mathbf{1}-\mathbf{3}$}

Ardisiacrispin D (1): white amorphous powder; $[\alpha]_{\mathrm{D}}^{27}=-26,(c=0.1, \mathrm{MeOH})$; HR-ESIMS m/z 805.4317 [M + Na] ${ }^{+}$(calcd for $\mathrm{C}_{41} \mathrm{H}_{66} \mathrm{O}_{14} \mathrm{Na}, m / z$ 805.4344); ${ }^{1} \mathrm{H}-\mathrm{NMR}$ (methanol- $d_{4}$, $400 \mathrm{MHz}$ ) and ${ }^{13} \mathrm{C}-\mathrm{NMR}$ (methanol- $d_{4}, 100 \mathrm{MHz}$ ), see Table 1.

Ardisiacrispin E (2): white amorphous powder; $[\alpha]_{\mathrm{D}}^{27}=-8,(c=0.05, \mathrm{MeOH})$; HR-ESIMS $m / z$ 821.4628 [M + Na] ${ }^{+}$(calcd for $\mathrm{C}_{42} \mathrm{H}_{70} \mathrm{O}_{14} \mathrm{Na}, m / z$ 821.4657); ${ }^{1} \mathrm{H}-\mathrm{NMR}$ (methanol- $d_{4}$, $400 \mathrm{MHz}$ ) and ${ }^{13} \mathrm{C}-\mathrm{NMR}$ (methanol- $d_{4}, 100 \mathrm{MHz}$ ), see Table 1.

Ardisiacrispin F (3): white amorphous powder; $[\alpha]_{\mathrm{D}}^{27}=+4,(c=0.05, \mathrm{MeOH})$; HR-ESIMS $m / z 789.4367[\mathrm{M}+\mathrm{Na}]^{+}\left(\right.$calcd for $\mathrm{C}_{41} \mathrm{H}_{66} \mathrm{O}_{13} \mathrm{Na}, m / z$ 789.4395); ${ }^{1} \mathrm{H}-\mathrm{NMR}$ (methanol- $d_{4}$, $400 \mathrm{MHz}$ ) and ${ }^{13} \mathrm{C}-\mathrm{NMR}$ (methanol- $d_{4}, 100 \mathrm{MHz}$ ), see Table 1.

\subsection{Acid Hydrolysis of Ardisiacrispin D-F (1-3)}

In order to determine the absolute configuration of the monosaccharide in triterpenoid saponins, the acid hydrolysis of new compounds were performed. The acid hydrolysis of ardisiacrispin D-F (1-3) (1.0 mg each) was performed according to the previous literatures $[20,25,26]$. The trimethylsilylthiazolidine derivatives from the $n$-hexane layer were analyzed with GC-MS with a DB-5 capillary column. The absolute configurations of the sugar moieties were established by comparison with the retention times of the authentic sugars (D-xylose, $15.56 \mathrm{~min}$; L-arabinofuranose, $16.40 \mathrm{~min}$; D-glucose, $18.21 \mathrm{~min}$ ).

\subsection{Cytotoxic Activity}

The cytotoxic activity of compounds (1-7) against three human cancer cell lines, namely Hela (human cervical cancer cells), HepG-2 (human hepatoma cells) and U87 MG (human glioblastoma cells), were evaluated by the MTT colorimetric assay described in a previous paper [27]. All the cells were cultured in DMEM supplemented with 10\% FBS and antibiotics in a humidified atmosphere containing $5 \% \mathrm{CO}_{2}$ at $37{ }^{\circ} \mathrm{C}$. Briefly, $100 \mu \mathrm{L}$ of adherent cells were seeded into each well of 96-well cell culture plates at optimal cell density $\left(1 \times 10^{5}\right.$ cells per well $)$ and allowed to adhere for $12 \mathrm{~h}$. The $\mathrm{IC}_{50}$ value of each compound was tested on the basis of cell viability after $48 \mathrm{~h}$ of treatment with different concentrations of compounds, with cisplatin (Sigma, >99\%) as the positive control.

\section{Conclusions}

To summarize, a total of seven 13,28 epoxy bridged oleanane-type triterpenoid saponins were isolated from the roots of $A$. crispa and 3 of them were new structures. In previous investigations, Ardisia species appeared to be a rich source of triterpenoid saponins and have significant cytotoxic activities. In this paper, compounds (1-7) were evaluated for the cytotoxicity against three cancer cell lines (HeLa, HepG2 and U87 MG) in vitro. Compounds 1, 4 and 6 exhibited significant cytotoxicity against Hela and U87 MG cells with $\mathrm{IC}_{50}$ values in the range of $2.2 \pm 0.6$ to $9.5 \pm 1.8 \mu \mathrm{M}$. The present investigation suggested that the roots of $A$. crispa could be a potential source of natural anti-tumor agents. Their triterpenoid saponins might be responsible for cytotoxicity, and also seem to be of great chemotaxonomic value for A. crispa. 
Supplementary Materials: The spectroscopic data for compounds 1-7 (Figures S1-S50) are available as Supporting Information. Table S1: ${ }^{13} \mathrm{C}-\mathrm{NMR}(100 \mathrm{MHz})$ Data of 4-7 in $\mathrm{CD}_{3} \mathrm{OD}$.

Author Contributions: Y.Z. (Ying Zhou) and X.Y. designed the experiments. X.Y., R.H. and Y.Z. (Yongqiang Zhou) performed the data analysis. R.H. and W.Z. isolated and purified the compounds. X.Y. wrote the article, while critical revision of the publication was performed by all authors. All authors have read and agreed to the published version of the manuscript.

Funding: The project was supported by the National Key Research and Development Program of China (No. 2018YFC1708100), National Natural Science Foundation of China (No. 82104538), Guizhou Education Department Youth Talents Growth Project (KY [2021]202), Qian Ke He Rencai Pingtai ([2019]5407) and Guizhou University of Traditional Chinese Medicine Startup Fund (2019-100 and 2019-101).

Institutional Review Board Statement: Not applicable.

Informed Consent Statement: Not applicable.

Data Availability Statement: Not available.

Conflicts of Interest: The authors declare no conflict of interest.

Sample Availability: Samples of all the isolated compounds are available from the authors.

\section{References}

1. Kobayashi, H.; Mejía, E. The genus Ardisia: A novel source of health-promoting compounds and phytopharmaceuticals. J. Ethnopharmacol. 2005, 96, 347-354. [CrossRef] [PubMed]

2. Chang, X.; Li, W.; Jia, Z.; Satou, T.; Fushiya, S.; Koike, K. Biologically active triterpenoid saponins from Ardisia japonica. J. Nat. Prod. 2007, 70, 179-187. [CrossRef]

3. Tian, Y.; Tang, H.F.; Qiu, F.; Wang, X.J.; Chen, X.L.; Wen, A.D. Triterpenoid saponins from Ardisia pusilla and their cytotoxic activity. Planta Med. 2009, 75, 70-75. [CrossRef] [PubMed]

4. $\mathrm{Mu}$, L.H.; Gong, Q.Q.; Zhao, H.X.; Liu, P. Triterpenoid saponins from Ardisia gigantifolia. Chem. Pharm. Bull. 2010, 58, 1248-1251. [CrossRef] [PubMed]

5. $\mathrm{Mu}$, L.H.; Wei, N.Y.; Liu, P. Cytotoxic triterpenoid saponins from Ardisia gigantifolia. Planta Med. 2012, 78, 617-621. [CrossRef] [PubMed]

6. Zheng, Z.F.; Xu, J.F.; Feng, Z.M.; Zhang, P.C. Cytotoxic triterpenoid saponins from the roots of Ardisia crenata. J. Asian Nat. Prod. Res. 2008, 10, 833-839. [CrossRef]

7. Gong, Q.Q.; Mu, L.H.; Liu, P.; Yang, S.L.; Wang, B.; Feng, Y.L. New triterpenoid sapoin from Ardisia gigantifolia Stapf. Chin. Chem. Lett. 2010, 21, 449-452. [CrossRef]

8. Tang, H.F.; Yun, J.; Lin, H.W.; Chen, X.L.; Wang, X.J.; Cheng, G. Two new triterpenoid saponins cytotoxic to human glioblastoma U251MG cells from Ardisia pusilla. Chem. Biodivers. 2009, 6, 1443-1452. [CrossRef]

9. Editorial Committee of Nan Jing University of Chinese Medicine, Chinese Materia Medica. Zhong Yao Da Ci Dian; Shanghai Science and Technology Press: Shanghai, China, 2014; Volume 1, p. 1181.

10. Nordin, M.L.; Kadir, A.A.; Zakaria, Z.A.; Abdullah, R.; Abdullah, M. In vitro investigation of cytotoxic and antioxidative activities of Ardisia crispa against breast cancer cell lines, MCF-7 and MDA-MB-231. BMC Complement. Altern. Med. 2018, 18, 87. [CrossRef]

11. Yeong, L.T.; Hamid, R.A.; Yazan, L.S.; Khaza'ai, H.; Mohtarrudin, N. Low dose triterpene-quinone fraction from Ardisia crispa root precludes chemical-induced mouse skin tumor promotion. BMC Complement. Altern. Med. 2015, 15, 431. [CrossRef]

12. Jun, L.W.; Foong, C.P.; Hamid, R.A. Ardisia crispa root hexane fraction suppressed angiogenesis in human umbilical vein endothelial cells (HUVECs) and in vivo zebrafish embryo model. Biomed. Pharmacother. 2019, 118, 109221. [CrossRef] [PubMed]

13. Yeong, L.T.; Hamid, R.A.; Yazan, L.S.; Khaza'ai, H.; Hamsin, D. Synergistic action of compounds isolated from the hexane extract of Ardisia crispa root against tumour-promoting effect, in vitro. Nat. Prod. Res. 2014, 28, 2026-2030. [CrossRef] [PubMed]

14. Hamid, R.A.; Othman, F.; Anthony, J.J.; Ting, Y.L. Chemopreventive effect of Ardisia crispa hexane fraction on the peri-initiation phase of mouse skin tumorigenesis. Med. Princ. Pract. 2013, 22, 357-361. [CrossRef] [PubMed]

15. Nordin, M.L.; Kadir, A.A.; Zakaria, Z.A.; Othman, F.; Abdullah, R.; Abdullah, M. Cytotoxicity and apoptosis induction of Ardisia crispa and its solvent partitions against Mus musculus mammary carcinoma cell line (4T1). Evid-Based Complement. Altern. Med. 2017, 2017, 9368079. [CrossRef]

16. Hamsin, D.; Hamid, R.A.; Yazan, L.S.; Taib, C.N.; Yeong, L.T. Ardisia crispa roots inhibit cyclooxygenase and suppress angiogenesis. BMC Complement. Altern. Med. 2014, 14, 102.

17. Hamsin, D.; Hamid, R.A.; Yazan, L.S.; Taib, C.N.; Yeong, L.T. The hexane fraction of Ardisia crispa Thunb. A. DC. roots inhibits inflammation-induced angiogenesis. BMC Complement. Altern. Med. 2013, 13, 5. [CrossRef]

18. Sulaiman, H.; Hamid, R.A.; Yeong, L.T.; Othman, F. Anti-tumor effect of Ardisia crispa hexane fraction on 7, 12-dimethylbenz[ $\alpha]$ anthraceneinduced mouse skin papillomagenesis. J. Cancer Res. Ther. 2012, 8, 404-410. 
19. Jia, Z.; Koike, K.; Ohmoto, T.; Ni, M. Triterpenoid saponins from Ardisia crenata. Phytochemistry 1994, 37, 1389-1396. [CrossRef]

20. Li, S.N.; Sun, J.F.; Wang, J.M.; Jin, L.; Zong, T.Q.; Zhou, W.; Li, G. Two new phenolic glycosides from the fruits of Illicium verum. J. Asian Nat. Prod. Res. 2021, 24, 31-38. [CrossRef]

21. Yamasaki, K.; Tanaka, O. Saponins from Vietnamese ginseng, Panax vietnamensis HA et Grushv. Collected in central Vietnam. II. Chem. Pharm. Bull. 1994, 42, 115-122.

22. Lavaud, C.; Massiot, G.; Moretti, C.; Men-Olivier, L.L. Triterpene saponins from Myrsine pellucida. Phytochemistry 1994, 37, 1671-1677. [CrossRef]

23. Mu, L.H.; Zhang, J.; Liu, P. Biotransformation and antitumor activity of triterpenoid derivatives from Ardisia gigantifolia. Chin. Tradit. Herb. Drugs 2018, 49, 1266-1271.

24. Huang, J.; Zhang, H.; Shimizu, N.; Takeda, T. Ardisimamillosides G and H, two new triterpenoid saponins from Ardisia mamillata. Chem. Pharm. Bull. 2003, 51, 875-877. [CrossRef]

25. Yin, X.; Liu, Y.; Pan, J.; Ye, H.L.; Sun, Y.; Zhao, D.Y.; Kuang, H.X.; Yang, B.Y. Melongenaterpenes A-L, Vetispirane-Type Sesquiterpenoids from the Roots of Solanum melongena. J. Nat. Prod. 2019, 82, 3242-3248. [CrossRef] [PubMed]

26. Yang, B.Y.; Yin, X.; Liu, Y.; Zhao, D.Y.; Kuang, H.X. New steroidal saponins from the roots of Solanum melongena L. Fitoterapia 2018, 128, 12-19. [CrossRef]

27. Yang, B.Y.; Yin, X.; Liu, Y.; Sun, Y.; Guan, W.; Zhou, Y.Y.; Kuang, H.X. Terpenes and lignans from the roots of Solanum melongena L. Nat. Prod. Res. 2020, 34, 359-368. [CrossRef] 